Chapter 8

\title{
Frack Off: Climate change, CSR, citizen activism and the shaping of national energy
} policy by David McQueen

Efforts to introduce hydraulic fracturing (or 'fracking') for oil and gas to Europe in recent years have met fierce public resistance, as well as worries from various commercial interests - such as brewers - about impacts on local water quality on which they depend. A combination of persistent protest, political lobbying and developing scientific concerns around the impacts of fracking have contributed to government-imposed moratoria and bans in a growing number of countries. In contrast to the shale boom in the US, particularly, but also in some Canadian and Australian states, shale oil and gas extraction in Europe has failed to gain the required political and public support to ensure widespread development. Concerns over noise, air and water pollution, tanker traffic and the industrialisation of the countryside in a densely populated continent, alongside urgent calls to switch from fossil fuels to preserve humanity's future, have led many to reject fracking as socially irresponsible and environmentally unacceptable.

October 2018 saw the first British fracking operation at the Preston New Road site in Lancashire operated by Cuadrilla Resources since a 2011 national moratorium following earth tremors around a drilling site close to Blackpool (The Telegraph 2017). Preston New Road has been a focal point for protest since 2016 when the government overturned a decision by Lancashire county council and gave Cuadrilla consent to extract shale gas at two wells on the site. The resumption of fracking in the UK has been met by public protests, controversial imprisonments, close scrutiny of seismic activity and media commentary on the British government's failure to implement effective policies in the fight against climate change. It also comes at a critical juncture in Europe for the development of shale gas and oil 
exploration and this chapter reflects, at this key moment, on the forces at play as well as the work of key individuals in the fight over fracking. The chapter concludes by considering if the technology can ever win the social licence required to be widely deployed in England, or further afield in Europe and ponders who holds responsibility for the future of this controversial process.

The fossil fuel sector has a long and well-documented history of pollution and destructive impacts on the environment and communities around the world with the paradoxical terms 'resource curse' or 'oil curse' often used to describe the negative effect of discovery and exploitation (Khanna 2017). Oil companies are consistently ranked among the least trusted corporations and most in need of more regulation (Corso cited Spangler and Pompper 2011). Furthermore, much of the industry's CSR activity is dismissed as 'greenwashing' (Spence $2017,397)$ designed to provide a buffer against criticism, regulation and efforts to scale back fossil fuel use. Indeed, the urgent requirement to drastically reduce reliance on fossil fuels has been underscored in the latest in a long line of UN Intergovernmental Panel on Climate Change Reports (IPCC 2018). The IPCC report noted that global net emissions of carbon dioxide would need to fall by 45 percent from 2010 levels by 2030 to keep global warming below 1.5 degrees Celsius. Without 'rapid, far-reaching and unprecedented changes in all aspects of society' (IPCC cited CNN 2018) the world will face more heat waves for tens of millions of people, enormous species loss, extreme weather events, increased water scarcity, food shortages, a ten-fold increase in Arctic ice-free summers and a total wipe-out of the world's coral reefs by 2040 (IPCC 2018; New York Times 2018). Despite repeated warnings of this kind since the 1980s, meaningful action on climate change remains 'painfully slow' with the oil and associated industries alongside other corporations with heavy environmental footprints attempting to 'frustrate meaningful progress' (Miller and Dinan 2015, 86). 
While the use of all fossil fuels, and especially coal, has come under increased scrutiny with this rising sense of urgency around climate change, the process of natural gas exploration by hydraulic fracturing of shale formations, or 'fracking', has taken on a number of specific concerns. There is alarm amongst environmentalists that the availability of cheaper gas undermines the economic viability of sustainable energies. In addition, the energy-intensive, unconventional techniques deployed in fracking for natural gas mean not only increased carbon dioxide but, more worryingly, methane emissions which are more than a hundred times greater at absorbing heat than CO2 (Howarth 2015). However, it is the experience of the local impacts of shale gas extraction and transportation that has helped galvanise powerful and sustained opposition to fracking. These impacts include the industrialisation of the countryside, the toxic contamination of drinking water, noise, light and air pollution, chronic illness, seismicity, the poisoning of agricultural land, chemical spills, accidents and explosions (Hannigan 2014; McQueen 2017). Evidence of these impacts have been widely shared using a variety of media through a dense network of local, regional and national protest movements, connected around the world through the internet and social media.

Public resistance to fracking in the United Kingdom has, therefore, been informed particularly by the U.S. and Australian experiences where fracking has a longer history of development and where both the industry and associated protests have been growing rapidly apace (Short and Szoluchab 2017). As recently as 2009, the words "shale gas" did not even appear in the annual U.S. government energy outlook, yet by 201023 percent of U.S. natural gas production had come from shale (Gross 2013) surging to nearly 70 percent of gas production in 2015 (EIA, cited US. EPA 2016, 4) Hydraulic fracturing also accounted for more than 50 percent of domestic oil production (Ibid) and the technology has enabled an important shift away from dependency on imported oil and gas and supports an estimated 725,000 jobs (Reuters 2015). It is estimated by the International Energy Agency (IEA) that 
US oil output could surpass Saudi Arabia's by 2020, making the country almost self-reliant (Bloomberg 2012). However, as Spence $(2017,390)$ observes, while this dramatic increase has undoubtedly benefitted the US economy, local communities around the rigs sustaining America's shale boom now experience some of the same the socioeconomic disruptions and environmental risks typically associated with the oil curse overseas.

Alongside the noise, lights, flares, and odours from fracking rigs, each time a well is fracked millions of litres of fresh water and chemicals must be delivered and toxic, often radioactive, fracked water needs to be stored in giant waste water pools, or removed from the site entirely. An average of more than 1,000 tanker truck trips are required per frack thereby taking a toll on local, often rural infrastructure not build for heavy traffic of this kind (Spence 2017), as well as increasing the number of road traffic accidents. In the development of The Energy Policy Act signed into law by George W Bush in 2005 the fracking industry successfully lobbied to be exempt from certain sections of the Clean Air Act (1970), Clean Water Act (1972) and Safe Drinking Water Act (1974) through the so-called 'Halliburton Loophole'. Controversially, companies do not have to disclose the chemical composition of their fracking fluids. This is justified on the basis of commercial sensitivity, yet many of the chemicals used in the fracking process are known to be 'caustic, poisonous, or explosive' (Wilber cited Hannigan, 2014, 189). An EPA report in 2016 found 'scientific evidence that hydraulic fracturing activities can impact drinking water resources under some circumstances' which has added pressure on fracking companies to publish a list of the more than 1,000 chemicals used in the fracking process (US. EPA 2016, 16).

A large part of the struggle against the fracking industry involves control over knowledgethe ability to define what is and what isn't a threat to health and the environment. The shale gas and oil drilling discourse is filled with struggles over 'facts', such as the toxicity of chemicals used in fracking fluids. As Gullion (2015) argues, while the foundations of policy 
making appear to rest on science; the science in question is mutable, particularly when cloaked by commercial confidentiality or underpinned by industry research grants. Even amongst scientists the facts are in dispute (see McQueen 2017) and 'epistemic privilege' is often granted to the more powerful (and well-funded) groups, while 'the groups in power try to eliminate all expressions of emotional pain from the discussion'. (Gullion 2015, 173)

Gullion uses the term 'reluctant activists' to describe the group of people she interviewed in Texas who are disproportionally burdened by the negative effects of natural gas development. The people in her research are neither poor nor (for the most part) members of racial or ethnic minority groups, but 'are living in a sacrifice zone' albeit one that is relatively prosperous:

Environmental problems can be a shock to these people, because they are typically sheltered from industrial activities. Used to buying their way to safety [...], they are often not aware of the difficulties of living in proximity to polluting industries (Gullion 2015, 173).

Gullion pinpoints the struggle over disputed scientific knowledge and the industry's efforts to close down discussion of lived experience of local fracking. Fear of health threats, confusion and a sense of powerlessness experienced by residents and farmers living close to fracking sites is a common theme in much of the critical scholarship and media coverage of the shale industry. Where local wells and ground water is contaminated by fracking the industry has sometimes provided bottled water on condition such supplies are not taken as an admission of liability. Payments for damage caused by seismicity, leaks and accidents are also often agreed with non-disclosure clauses that prevent those most affected from sharing their experiences with others (Insurance Journal 2013; DutchNews.nl 2016). Resistance to local fracking is expensive, stressful and traumatic (Short and Szoluchab 2017) and networks of fellow protestors often provide the only sympathetic venue to express frustration. Yet resistance in 
the US and Australia continues to grows and the efforts of individuals captured in documentaries, blogs and creative protest has inspired those in neighbouring states and other countries facing the same issues.

A series of powerful and disturbing films documenting local experience of shale gas exploration in the US and beyond have helped galvanise domestic and international opposition to fracking. These include Split Estate (2009); Gasland (2010); Gasland Part 2 (2013); Fractured Land (2015), Frackman (2015), as well as hundreds of low-budget, locally-produced reports and documentaries made in areas affected by, or threatened with the possibility of fracking. The most influential of these is undoubtedly Academy-Awardnominated Gasland written and directed by Josh Fox who travels across twenty-four US states impacted by unconventional hydrocarbon extraction talking to people whose lives have been blighted by polluted air and drinking water, destruction of property value, ill health and even an exploding well (Hannigan 2014). Mazur (2014) argues that before April 2010 major US news organizations paid little attention to the issue of fracking, but that following the offshore Deepwater Horizon disaster of that month The New York Times and other media outlets began to report more frequently on potential risks of the onshore exploration of shale gas that Gasland had exposed.

The continuing effect of Josh Fox's individual contribution to the fracking debate is hard to measure, but what is clear is the filmmaker's tenacity and skill in collating and publicising the hidden fallout of shale gas development across the country. Gasland and Fox's follow-up documentary Gasland 2 explore the negative impacts of fracking that the mainstream media had often failed to report on, alongside the emotional toll that challenging the industry has taken on families and communities. His films and other documentaries that came in their wake have been used by environmental activists to help mobilise local communities against the threat of fracking around the world. 
The shale industry quickly woke to the 'Gasland effect' and has fought back against the films and the movement they spurred in a number of ways. They sponsored films such as Shale Gas and America's Future (2010) released by the American Clean Skies Foundation, a pronatural gas industry group (Natural Gas Intel 2012) and Truthland (2013), which benefitted from a \$1 million grant from America’s Natural Gas Alliance (The Nation 2013).

Fracknation (2013) another film made in direct response to the Gasland films, alongside Not Evil Just Wrong: the True Cost of Global Warming Hysteria (2009) by the same director Phelim McAleer, were also promoted and received logistical support by industry lobbyists.

A loose coalition of free-market foundations and fossil fuel lobbyists has also funded socalled AstroTurf groups, educational material for schools, think tanks, academic and industry research, online and media campaigns in favour of fracking. Americans for Prosperity Foundation and The Heartland Institute, both funded by the Koch brothers, The Heritage Foundation, The Cato Institute, The Competitive Enterprise Institute, Koch Industries and the American Petroleum Institute (API) are amongst the US organisations championing unconventional oil and gas drilling as well as promoting climate change denial and scepticism. These and other conservative foundations press for accelerated investment in domestic oil and gas exploration, extolling the security virtues of reducing dependency on imported fossil fuels, whilst casting doubt on climate change science and frustrating policy efforts on climate action (Miller and Dinan 2015). The success of these groups can partly be measured by the decision in 2017 by President Donald Trump, who describes climate change as a 'hoax', to withdraw from the Paris Agreement on climate change mitigation and prioritise fossil fuel infrastructure projects which had been held up by the Obama administration (Piper and McQueen 2018). The close cooperation of the US Environmental Protection Agency (EPA) with The Heartland Institute and other climate sceptic groups (AP News 2018) under Scott Pruitt and the slashing of environmental regulations under Andrew 
Wheeler, the new acting chief of the agency, a former coal lobbyist (New York Times 2018), is further indication of the Trump administration's close cooperation with fossil fuel lobby groups.

A study by Robert Brulle in the journal Climatic Change (2014) shows 91 organizations in the US that make up what he describes as 'the climate change counter-movement' (CCCM) received an annual income of just over $\$ 900$ million between 2003-2010, much of which came through trusts or other mechanisms that assure anonymity to donors. Researching such funding is problematic, but one estimate indicated the Koch Brothers alone have donated \$61million to the CCCM (Cave and Rowell 2014, 224) suggesting the power individuals can have in shaping public discourse around climate change.

Many US conservative foundations and fossil-fuel lobby groups have developed ties with members of the British political establishment directly, or via the Global Warming Policy Foundation (GWPF) founded by Lord Nigel Lawson, The Institute of Economic Affairs (IEA), Economists for Free Trade (EFT) and other think tanks. Their pro-fossil fuel, anticlimate action agenda can be seen in the Conservative Party's shift away from the 'Vote Blue, Go Green' strategy led by David Cameron and encoded in a statement of Conservative principles, Built to Last, published in August 2006, (Carter and Clements 2015, 207). Cameron who in 2010 promised, as the head of the Conservative-Liberal Democrat Alliance to lead the 'greenest government ever' was by 2013 failing to challenge the growth of climate science denial in his own party and reportedly demanding that aides 'get rid of all the green crap' (green levies and regulations) that he regarded as responsible for pushing up energy prices (Carter and Clements 2015, 215). A Downing Street source allegedly remarked: "We used to say: 'Vote blue, go green', now it's: 'Vote blue, get real'." (cited The Guardian 2013). 
As Hannigan (2014) notes, the ruling Conservative/Liberal Democrat coalition was divided between a pro-growth wing and an environmental wing. The former enthusiastically embraced fracking, seeing it as the key to energy security and economic prosperity. The latter faction worried that fracking would industrialize the countryside and make it difficult to justify subsidies for renewable energy projects. In addition, Tory Members of Parliament from rural constituencies who tended to be hostile to renewable energy projects such as wind farms, were unlikely to welcome fracking rigs in their backyards - 'especially in the 'stockbroker belt', the rolling countryside in Surrey and Sussex south of London where an estimated 700 million barrels of recoverable shale oil have been forecast'. (Hannigan 2014, 179).

Influenced by the pressures from within the party, the right wing press, and a more sceptical Conservative-supporting base, the Conservative Governments under David Cameron from 2015 and Teresa May from 2016 appeared to lose interest in meaningful efforts at tackling climate change. The government ended much of its support for renewable energy dramatically cutting subsidies to the solar industry leading to 12,000 job losses in the sector in a single year (Guardian 2016) and effectively prohibiting onshore wind turbines whilst 'going all out for shale' (McQueen 2017, 222). For Carter and Clements this direction of travel was an unsurprising development:

The right is climate sceptic or 'climate go-slow' because it is anti-regulation, pro-market, anti-state, anti-EU, anti-taxes, so it is very hard to construct a 'conversation' or 'narrative' where positive action to mitigate climate change fits comfortably. (Carter and Clements 2015, 217)

Potential future leaders of the Conservative Party and arch-Brexiteers Boris Johnson, Michael Gove and Jacob Rees-Mogg are widely regarded as climate change sceptics, or at least 
sceptical of legislation designed to reduce greenhouse gas emissions. Yet their 'go-slow' on climate action can trace its roots back at least to 2011 with a speech by George Osborne at the Conservative Party Conference in Manchester that year, which put him on a collision course with the government's then coalition partners the Liberal Democrats (The Independent 2011). The downgrading of green energy schemes and the 'dash for gas' announced in 2012 by David Cameron quadrupled the amount of power expected to be generated from gas by 2030 and made it more likely that the UK would be unable to meet its carbon emission targets (The Observer 2012). Blocking the development of onshore and even some offshore windfarms, such as Navitus Bay (Telegraph 2015), whilst offering tax incentives to frack for gas struck many environmentalists as perverse, but it indicates that the gap between the policies of the Trump administration in the US and that of the UK's British Conservative Government may be more a matter of presentation than of substance.

Protests against fracking and associated pipeline construction have, arguably, contributed in some cases to state or county-wide bans or moratoria in the US (see McQueen 2018), but they have failed to prevent both Democrat and Republican administrations from encouraging the shale boom across the nation. Opposition to shale gas drilling is, however, much more intense in Western Europe than it is in southern Ohio or upstate New York (Levi 2013). Environmental concerns and protests, particularly related to the danger to water supplies and impacts to the countryside in a densely populated continent, have slowed adoption of the practice in Europe. The European Union currently lacks a unified stance on fracking and while banned in Germany and France, Poland, for one has resisted calls for restrictive European legislation on shale gas to protect its energy independence from Russia (New York Times 2012).

Have public protests played a part in slowing the progress of hydraulic fracturing across the continent? France, for instance, has the twelfth biggest reserves of shale gas in the world and 
yet protests and 'a highly charged and emotional debate' (Chaineau and Lennock. 2016, 1) resulted in an effective ban on hydraulic fracturing by the centre-right government of former President Nicolas Sarkozy in 2011, which was upheld by the constitutional court in 2013. While the nation's reliance on nuclear energy meant that France was perhaps not as anxious to develop locally fracked gas resources as other nations, the likelihood of further protest action from farmers, wine producers and citizens with a history of militant protest is likely to have been a strong consideration.

Bulgaria became the second country in Europe to ban fracking in January 2012 following large-scale and persistent street protests against Chevron (BBC 2012). Chevron was also forced to suspend its plans to drill an exploratory well in neighbouring Romania in the village of Pungesti, in an economically depressed area near the Moldovan border following sustained opposition by local residents and farmers. The local community protested and blocked the company from entering the area for two months. In a detailed report on EJ Atlas (2018) noted how:

An activist in Bucharest, who acts as a liaison with people in Pungesti, said people in remote areas are now knowledgeable about the well-publicized problems like water pollution that opponents say fracking has caused in the United States and they are well-connected with a European network and international network.

After weeks of intense policing and allegations of brutality against protestors Chevron finally pulled out of Romania 'due to poor exploration results and prolonged protests by environmentalists'. This withdrawal from the fracking project marked the end of the company's shale gas exploration in Europe (EJ Atlas 2018). Other protests in Poland and Ukraine are far less likely to halt unconventional hydrocarbon extraction in countries which 
are anxious to end their dependency on Russian imported gas, but they may have also slowed progress in developing the countries' shale gas resources.

In Germany long-running and large-scale protests against nuclear energy undoubtedly contributed to Angela Merkel's CDU government decision in 2011 to phase out nuclear power stations by 2022, but it was not the only factor. The Fukishima disaster of 2011 was proclaimed as the immediate catalyst for the Merkel administration to accelerate an earlier commitment by the government of Gerhard Schroeder (SPD) to phase out nuclear power. Merkel won early support for the suspension with an ARD poll showing 80 percent support for the decision, with 53 percent backing closure of all German reactors as soon as possible (Reuters 2011). However, this represented a handbrake turn on energy policy for the CDU and opposition parties accused Merkel of 'transparent trickery' in response to the prospect of the CDU faced losing control of Baden-Württemberg in imminent regional elections. Nuclear power plants were unpopular nationally and the move was seen as an effective method of neutralising the anti-nuclear opposition. The decision, described as 'overly hasty' by former Chancellor Helmut Kohl (Spiegel 2011), did not prevent electoral defeat for the CDU in the Baden-Württemberg state election of 27 March 2011 which saw a doubling of the Green vote. The sudden reversal in policy position taken by the Christian Democrats in the field of nuclear energy policy 'simply lacked credibility', whilst the media and public mostly agreed that the catastrophe in Fukushima mobilised people to vote, and especially to vote for The Green Party which has rejected the use of nuclear energy since its foundation (Keil and Gabriel 2012, 240).

Similarly, it is likely that citizens' protests alone did not cause the German government to ban fracking in 2016 and that other electoral and commercial concerns, as in France, have played a role. In May, 2013, the Association of German Breweries voiced its grave concern to the federal cabinet that fracking could violate the 500-year-old Bavarian purity law, which only 
allows water, barley, hops and yeast, and endanger the water supply that more than half Germany's breweries currently take from private wells (Nicola cited Hannigan 2014, 177). Unpicking the various factors that lead to legislative change is undoubtedly, a complex process. In October 2018, neither 50,000 anti-coal demonstrators in the Hambach Forest, nor the presence of tree-house protestors for several years on the threatened site have (at the time of writing) halted German energy giant RWE's plans to begin clearing half of the forest's remaining 200 hectares of woodlands (Deutsche Welle 2018), nor its support from the German government. Other political and economic factors and opposition forces may have to come into play

In the Netherlands a complex of factors are thought to have helped sway the Dutch government to impose a moratorium in 2015 and confirm the permanent end to shale gas drilling in 2018. As in Germany, objections by brewing groups like Heineken, alongside opposition by a number of local councils, water boards and citizen groups played their part. The experience of residents affected by strong earth tremors and subsidence in the Groningen area where 100,000 homes are estimated to have suffered damage as a result of decades of gas exploration has also helped focus the minds of legislators on the probable long-term seismic impact of fracking (DutchNews.nl 2016, 2018; Deutsche Welle 2017).

In Spain, grassroots opposition to fracking has led to bans on fracking in four regions Cantabria, La Rioja and Navarra (since 2013) and Catalonia (since 2014). According to a report in EJOLT (2013) the use of community workshops to explain the threat of fracking were highly effective in a decentralised campaign in Cantabria and nationwide public opposition to fracking is rapidly spreading with more than 400 towns declaring themselves fracking-free towns. In the Basque Country and in Asturias and Burgos several fracking companies have, the report states, 'given up due to opposition and public pressure'. Similarly, a 2012 moratorium on fracking in Denmark was due to come to an end in 2015, but the 
French oil and gas giant Total decided to abandon its shale gas exploration plans in 2016 'following poor results from initial drilling in north Jutland and overwhelming public resistance' (Copenhagen Post 2016).

Despite these setbacks for the fracking industry on the continent, fracking recommenced in Britain on the $15^{\text {th }}$ October 2018 after a seven year pause. This followed a moratorium imposed by the British government after minor earthquakes were detected in the Blackpool area close to Cuadrilla's Preece Hall site in the spring of 2011 which was lifted at the end of 2012. Protests against Cuadrilla in 2013 at Balcombe in West Sussex, against Third Energy's exploratory drilling at Kirby Misperton in Yorkshire, against the drilling of a shale well at Barton Moss in Salford by iGas and in Lancashire at Cuadrilla's Preston New Road and Roseacre Wood sites have failed, so far, to halt the British government's determination to support the shale industry. This determination was bolstered by lobbying and interventions by industry personnel and experts at the heart of Whitehall ministries and the Cabinet Office (McQueen 2017). Westminster's policy rhetoric emphasises economic development, regulatory oversight and distribution of benefits to local communities, whilst minimising discussion of the implications of shale gas for anthropogenic climate change (Cotton et al. 2014), amongst other impacts discussed above.

Nevertheless, the scale and determination of day-to-day protests has slowed work at the drilling sites in Lancashire and Yorkshire and may have halted operations at Balcombe where Cuadrilla denied ever wanting to frack due to the nature of the rock. While day-to-day protests rarely made news headlines, the arrest of individuals sometimes did. Greatgrandmother Jackie Brookes, 79, who set up a table for serving tea and cakes to both protesters and police at the Kirby Misperton site in North Yorkshire in September and October 2017 was arrested on $9^{\text {th }}$ October after she and other protesters refused orders by police to 'step away from the picnic table' set up near the site (The Metro 2017). Even pro- 
conservative and pro-fracking newspapers The Sun and Daily Mail considered the arrest an over-reaction - with 'TWELVE' (emphasis in original) policemen noted in the Daily Mail headline which also quoted protestors as shouting 'This is England, not 1930s Germany'. The Sun strapline described the arrest shown in a large photograph which dominated coverage in several papers as follows: 'This is the shocking moment an elderly tea lady was forcibly moved from her month long post set up at a controversial fracking site by police'. Here the power of images played a part as photographs of young uniformed police arresting an innocuous-looking, white-haired lady at her tea stall clearly disturbed a faction of Middle England normally unsympathetic to anti-fracking protestors.

The following day, across the Pennines in Lancashire outside Cuadrilla's Preston New Road site, an 81 year old disabled protester Anne Power was sitting in a folding chair by the side of the road. Campaigners were listening to speeches at what has become a regular "Green Monday" event when a tanker reportedly drove through the crowd, waved in by Cuadrilla security staff. This prompted people to sit down in protest, which led to the arrest of Anne Power who was photographed being dragged across the road by three uniformed police officers. The arrest also gained some mainstream media coverage, but social media widely recirculated the image side-by-side to that of a Suffragette being dragged by policemen in a strikingly similar pose with the text: 1910 - Suffragette; 2017 anti-fracker under each photo. The meme strapline was 'Over 100 years and the police are still on the wrong side of history'. The most media coverage however went to three protestors imprisoned for their part in a four-day direct action protest that blocked a convoy of trucks carrying drilling equipment from entering the Preston New Road fracking site in Little Plumpton, near Blackpool. Simon Blevins, 26, and Richard Roberts, 36, were sentenced to 16 months in prison and Richard Loizou, 31, received a 15-month sentence after being convicted of causing a public nuisance climbing onto lorries outside Cuadrilla's fracking site by a jury at Preston crown court. 
Another defendant, Julian Brock, 47, was given a 12-month suspended sentence after pleading guilty to the same offence in a trial where the defendants could not talk about why they were concerned about fracking, 'or explain that many people in the community welcomed being mildly inconvenienced if it delayed and deterred the much greater threat of fracking and climate change' (Lucas 2018). According to a lawyer representing them, the three men were the first environmental campaigners to be jailed for a protest in the UK since the mass trespass on Kinder Scout in the Peak District in 1932. Judge Robert Altham was widely criticised for the draconian sentence against non-violent protestors and for allegedly having a conflict of interest due to his family's links to the gas and oil industry. The sentence was deemed 'manifestly excessive' (The Times 2018) on appeal and the three were released a week later to a hero's welcome from anti-fracking protestors. Widespread media coverage for their arrest and release gave them a rare opportunity to explain their reasons for protesting to the mainstream media. The fact that one, Simon Blevins, was a soil scientist alarmed at the impact fracking would have on the soil lent further credence to those who doubted the government's claim science supported the case for fracking. Have these protests and attendant publicity had any impact on the government's plans to go 'all out for shale'?

In 2018 the Conservative Government under Teresa May enjoys a slim majority in Parliament with the support of the Democratic Unionist Party (DUP), which Ian Johnston of The Independent described as 'a far-right party with a track record of Donald Trump-style climate change denial'. Indeed, the DUP's former environment minister once described global warming as a 'con' and the Paris Agreement on climate action as 'a delusion' in language reminiscent of President Trump (The Independent 2017). Yet the government has faced protracted legal battles and protests against the return of fracking across the UK and the other major Parliamentary parties have now vowed to oppose fracking. In 2016 the Labour Party announced it would ban the process and the Liberal Democrats added a ban to their 
2017 manifesto. The same year the Scottish SNP government banned fracking after a consultation found overwhelming public opposition and little economic justification for the industry (The Guardian 2017). This followed a two year moratorium on fracking in Scotland from 2015. In 2015 the Welsh government also imposed a moratorium and are likely to permanently ban the process, or indeed any coal bed methane extraction, arguing that the 'benefits of petroleum extraction are not great enough to outweigh its commitment to sustainably manage natural resources' (National Assembly for Wales Research Service 2018). Northern Ireland ruled out fracking in 2014 following sustained protests in County Fermanagh (Belfast Telegraph 2014) and in the Republic of Ireland legislation banning fracking was passed in 2017 in the first Private Members' Bill to be passed by both Houses during the lifetime of the minority Government (Irish Times 2017). These bans followed protest and pressure from civil society that has been harder to resist or ignore in national parliaments than in Westminster. England remains the sole country in the British Isles where fracking is permitted and the scale of opposition in the regions - Lancashire, Yorkshire and Sussex where exploratory drilling has taken place - suggests drilling on a large scale across the English countryside is an unrealistic ambition. Craig Bennett writing in The Independent in reaction to Ireland's vote to ban shale gas exploration argued:

'Leaders of the Labour, Liberal Democrat and Green parties have all said they would oppose fracking in their manifestos. In addition, Scotland, Wales, and Northern Ireland have all put in place their own suspensions of fracking, which means whatever the election result large sections of the UK are already off the table as a source of shale gas' (Bennett 2017)

It certainly appears that, while just under 50 percent of the population continues to hold no strong views either for or against fracking, public opinion has been turning against it and it is now regarded as the least favoured potential source of energy for the UK with more than 
double the amount of people opposed (33 percent) to fracking than support it (16 percent) in 2017 - a complete turnaround from 2013 when more were in favour of fracking than opposed it. A sign of the government's discomfort at these poll findings is the decision in 2018 to no longer ask this question in surveys.

The success or failure of the government's current energy strategy may ultimately be down to the level and intensity of local protests where sustained direct action requires huge time and energy commitment by groups of dedicated individuals. At Preston New Road Henry Owen, who locked himself to the top of a scaffold to impede Cuadrilla's work at the site in October 2018, told The Guardian it was important to continue demonstrating:

"It's absolutely vital because this industry has no social licence in the UK," he said. “It's being pushed through by government who don't care about their commitments to take action on climate change. They're not interested in what local communities have to say. After all democratic avenues have been exhausted over a seven-year campaign, there is a place for direct action to stop this industry." (Guardian 2018a)

This sums up some of the core arguments of protestors who have been on the front line of protests against fracking in the UK. This chapter has indicated that their arguments have gained traction across the British Isles with bans or moratoria now operating in Ireland, Scotland and Wales. Media coverage of fracking in the UK has often echoed industry reassurances on the safety of the technology (McQueen 2017). In Britain as in the US and Poland journalists have, for the most part, offered framing of the debate set by the government and representatives from the fracking industry, which focus on the benefits of the process for the economy and for national energy security and which downplay potential hazards. Matthews and Hansen (2018) note this generic framing occupies a privileged position in the overall reporting of hydraulic fracturing and resonates with the publics' 
concerns over "affordable energy" whilst countering the communication of the associated risks.

However, they also note problems in sustaining a pro-fracking discourse in media reporting over time or challenging environmental concerns with trusted spokespersons independent of the fracking industry. Anti-fracking views now find a place among the general influences shaping media coverage and fracking is now reported as a mainstream, and controversial, news story rather than a business story. The authors indicate that research points to the influence of anti-fracking media, whether by documentary via YouTube or social media:

Observing the mobilized protest activities that have emerged alongside online media and conversation and their interests in "local issues, local concerns and local needs" of affected citizens (Bomberg, 2017: p. 86), helps to reveal the interconnected influences that are informing the media reporting of environmental risks and the potential threats associated with the hydraulic fracturing process'. (Matthews and Hansen 2018)

At the end of this short survey of the present state of the debate around fracking in Europe and the UK at a crucial turning point in its development it is worth reflecting on the power of individuals. Politicians, such as President Donald Trump and powerful, wealthy lobbyists, such as the Koch brothers, have enormous power to shape public perceptions and political decision-making in the US and beyond. However, individual protestors, such as 79-year-old Jackie Brookes, 81-year-old Anne Power, or Simon Roscoe Blevins, Richard Roberts and Richard Loizou whose arrests achieved national media coverage can also help shape the debate around fracking in the UK. These citizens' commitment to a collective protest, even at the expense of their liberty, may be helping to change the terms of the national conversation on the country's energy strategy, a policy area usually left to the expertise of government and 
energy specialists. Public support for fracking is falling and protests continue to make headlines and to slow progress at drilling sites, such as Preston New Road, dogged by daily earth tremors in October 2018. This combination of factors may see the political will to push fracking through tested to the limits. Conservative MP Zac Goldsmith has already indicated the possibility that fracking may damage his party in forthcoming elections if local planning rules are changed to allow fracking. In an interview with The Guardian in October 2018, Goldsmith said:

"Fracking is an issue that has the potential to turn whole regions against the government. The drilling rigs and pollution, the industrial equipment and sheer volume of trucks all make it an alarming prospect for communities up and down the country."

Goldsmith noted that some Conservative MPs had been angered by the proposed planning changes, which would allow shale gas wells to be drilled without the need for planning permission and class fracking sites as nationally significant infrastructure, adding:

"If the government's answer is simply to change the planning rules so that even elected local representatives have no say on the issue, then it will have to be prepared for a huge backlash" (The Guardian 2018b).

This chapter has noted a fast moving and fluid situation in Europe around unconventional hydrocarbon extraction with many countries banning hydraulic fracturing between 2011 and 2018. The snapshot of the current situation provided here offers a chance to reflect on the forces at play in the contentious debate around fracking. Critical studies of the energy sector pay attention to the alarming warnings coming from the IPCC and other scientific bodies on the need to dramatically slash our dependence on fossil fuels. These studies describe energy intensive technologies such as fracking as unsustainable and irresponsible. The 'responsible 
people', in this debate, this chapter suggests, are those who oppose these technologies, often at great cost to themselves and with little personal reward. The protestors in Lancashire, Yorkshire and across Europe who challenge environmentally unsustainable energy development, such as fracking, are protecting scarce natural resources and challenging corporate irresponsibility. As individual researchers and citizens we too need to take responsibility for our collective future and challenge corporate interests where they are clearly at odds with the public interest and the future of this planet as they are in the fracking industry.

\section{Bibliography}

AP News. 2018. Emails show cooperation among EPA, climate-change deniers. AP News 25 May 25. Accessed October 10, 2018, https://apnews.com/64cd37b0503440c0b92e6ca075f87dd4.

BBC. 2012. Bulgaria bans shale gas drilling with 'fracking' method. BBC January 19. Accessed October 12, 2018, https://www.bbc.com/news/world-europe-16626580.

Belfast Telegraph. 2014. Fracking: Drilling will not be allowed in Northern Ireland unless it's proven safe, warns Environment Minister Mark H Durkan. Belfast Telegraph. Accessed October 12, 2018, https://www.belfasttelegraph.co.uk/business/news/fracking-drilling-willnot-be-allowed-in-northern-ireland-unless-its-proven-safe-warns-environment-minister-markh-durkan-30469238.html.

Bennett, Craig. 2017. Ireland is the latest European country to ban fracking - the Tories need to follow suit. The Independent. Accessed October 14, 2018, https://www.independent.co.uk/voices/fracking-environment-ireland-theresa-maya7771956.html. 
Bloomberg. 2012. U.S. Oil Output to Overtake Saudi Arabia’s by 2020. November 12. Bloomberg. https://www.bloomberg.com/news/articles/2012-11-12/u-s-to-overtake-saudiarabia-s-oil-production-by-2020-iea-says

Brulle, Robert. 2014. "Institutionalizing Delay: Foundation Funding and the Creation of U.S. Climate Change Counter-Movement Organizations." Climatic Change 122 (4): 681-94.

Carter, Neil, and Ben Clements. 2015. "From 'Greenest Government Ever' to 'Get Rid of All the Green Crap': David Cameron, the Conservatives and the Environment." British Politics 10 (2): 204.

Cave, Tamasin and Andy Rowell. 2014. A Quiet Word: Lobbying, Crony Capitalism and Broken Politics in Britain. Random House, London.

Chaineau, Claude-Henri, and Jean Lennock. 2016. "Stakeholder Engagement on Shale Gas in Europe: Has It Already Failed?” SPE International Conference on Health, Safety \& Environment in Oil and Gas Exploration and Production, 1620.

CNN, 2018. Planet has only until 2030 to stem catastrophic climate change, experts warn. Accessed October 21, 2018 at: https://edition.cnn.com/2018/10/07/world/climate-changenew-ipcc-report-wxc/index.html.

Copenhagen Post. Total gives up fracking plans in Denmark. Copenhagen Post, June 1, 2016. Accessed 21/10/18 at: http://cphpost.dk/news/total-gives-up-fracking-plans-in-denmark.html Cotton, Matthew, Rattle, Imogen and James Van Alstine, J. Shale gas policy in the United Kingdom: An argumentative discourse analysis. Energy Policy, no. 73. (2014) 427 - 438 Deutsche Welle. Earthquake Damage in the Netherlands. DW, September 21, 2017. Accessed 13/10/2018 at: https://www.dw.com/en/earthquake-damage-in-the-netherlands/av-40597733 
Deutsche Welle. Germany: Thousands hold anti-coal protest in Hambach Forest. $D W$, October 6, 2018. Accessed 13/10/2018 at: https://www.dw.com/en/germany-thousands-holdanti-coal-protest-in-hambach-forest/a-45779366

DutchNews.nl. Shored-up homes are a common sight in earthquake-hit Groningen.

DutchNews.nl. June 2, 2016. Accessed 10/10/2018 at:

https://www.dutchnews.nl/features/2016/06/91027/.

DutchNews.nl. 2018. Dutch minister confirms ban on drilling, shale gas 'not an option'.

DutchNews.nl. 26 October. Accessed 10/10/2018 at:

https://www.dutchnews.nl/news/2018/02/dutch-minister-confirms-ban-on-drilling-shale-gasnot-an-option/.

EJOLT. Fracking ban expanded in Spanish Regions. February 10, 2013. Environmental Justice Organisations, Liabilities and Trade. Accessed 10/10/2018 at:

http://www.ejolt.org/2014/02/fracking-ban-expanding-in-spanish-regions/

EJ Atlas. Pungesti's resistance to Chevron Gas Fracking, Romania. Environmental Justice Atlas. 2018, accessed 10/10/2018 at: https://ejatlas.org/conflict/resistance-to-shale-gasfracking.

Gross, Michael. Dash for gas leaves Earth to fry. Current Biology 23, no. 20 (2013) 901-904.

Gullion, Jessica Smartt. Fracking the Neighborhood: Reluctant Activists and Natural Gas Drilling. Cambridge: MIT Press, 2015.

The Guardian. David Cameron at centre of 'get rid of all the green crap' storm. Nov 21, 2013. The Guardian. Accessed 07/10/2018 at: https://www.theguardian.com/environment/2013/nov/21/david-cameron-green-crapcomments-storm. 
The Guardian. Solar subsidy cuts lead to loss of 12,000 jobs. July 25, 2016. The Guardian. Accessed 07/10/2018 at: https://www.theguardian.com/environment/2016/jul/25/solarsubsidy-cuts-lead-to-loss-of-12000-jobs.

The Guardian. Scottish government bans fracking after public opposition. October 3, 2017. The Guardian. Accessed 12/10/2018 at: https://www.theguardian.com/uknews/2017/oct/03/scottish-government-bans-fracking-scotland-paul-wheelhouse.

The Guardian. Anger and blockades as fracking starts in UK for first time since 2011. October 15, 2018a. The Guardian. Accessed 20/10/2018 at: https://www.theguardian.com/environment/2018/oct/15/fracking-protesters-blockadecuadrilla-site-where-uk-work-due-to-restart.

The Guardian Fracking risks turning country against Tories, says Zac Goldsmith. The Guardian October 28, 2018b. Accessed 28/10/2018 at:.https://www.theguardian.com/environment/2018/oct/28/fracking-turning-country-torieszac-goldsmith-conservative-drilling.

Hannigan, John. Environmental Sociology. London: Routledge, 2014.

Howarth, Robert W. 2015. Methane emissions and climatic warming risk from hydraulic fracturing and shale gas development: implications for policy. Energy and Emission Control Technologies. Vol. 3 Pages 45-54. Dove Press.

The Independent. Osborne's anti-green agenda splits Coalition. The Independent. October 26, 2011. Accessed 20/10/2018 at: https://www.independent.co.uk/environment/greenliving/osbornes-anti-green-agenda-splits-coalition-2375993.html.

The Independent. DUP condemned for climate change denial of Trump-style proportions. The Independent, June 9, 2017. Accessed on 14/10/2018 at: 
https://www.independent.co.uk/news/uk/politics/dup-climate-change-denial-hungparliament-election-results-trump-a7781681.html.

Insurance Journal. Fracking Companies Silence Water Complaints with Sealed Settlements. 10 June. Insurance Journal. (2013). Accessed on 17/10/2018 at: https://www.insurancejournal.com/news/national/2013/06/10/294608.htm.

IPCC IPCC Special Report. 2018. Accessed 18/10/2018 at: http://www.ipcc.ch/report/sr15/. The Irish Times. Ireland joins France, Germany and Bulgaria in banning fracking. The Irish Times. June 28, 2017. Accessed 15/10/2018 at: https://www.irishtimes.com/news/politics/oireachtas/ireland-joins-france-germany-andbulgaria-in-banning-fracking-1.3137095.

Keil, Silke and Oscar Gabriel. The Baden-Württemberg State Election of 2011: A Political Landslide. German Politics, 21:2, (2012): 239-246.

Khanna, Arpita Asha. "Revisiting the Oil Curse: Does Ownership Matter?” World Development 99 November (2017): 214-29

Levi, Michael A. The Power Surge : Energy, Opportunity, and the Battle for America's Future. New York: Oxford University Press, 2013.

Lucas, Caroline. The jailing of fracking protesters tells us we are winning this fight. The Guardian. September 26, 2018. Accessed 18/10/2018 at: https://www.theguardian.com/commentisfree/2018/sep/26/jailing-fracking-protesters-fightcaroline-lucas.

Mazur, Allan. "How Did the Fracking Controversy Emerge in the Period 2010-2012?" Public Understanding of Science 25, no. 2 (2014): 207-22. 
Matthews, Julian and Anders Hansen. Fracturing Debate? A Review of Research on Media Coverage of "Fracking". Frontiers in Communication 3 no. 41 (2018) 1-11.

The Metro. Tea Lady 79 is grabbed by 12 Police While Supplying Tea to Anti-Fracking Protestors. The Metro, October 10, 2017. Accessed 15/10/2018 at: http://metro.co.uk/2017/10/10/tea-lady-79-is-grabbed-by-12-police-while-supplying-tea-toanti-fracking-protesters-6990204/.

McQueen, David. Fear, loathing and shale gas. The introduction of fracking to the UK: a case study. In Theofilou, A., Grigore, G. and Stancu, A. (eds) Corporate Social Responsibility in the Post Financial Crisis - CSR conceptualisations and international practices in times of uncertainty. London: Palgrave Macmillan, 2017.

McQueen, David. Turning a deaf ear to the citizen's voice. Digital Activism and corporate (ir)responsibility in the North Dakota Access Pipeline Protest. In: Corporate Responsibility and Digital Communities - An International Perspective towards Sustainability (2018). Edited by Georgiana Grigore, Alin Stancu, David McQueen. London: Palgrave Macmillan, 2018.

Miller, David and Dinan, William. Resisting Meaningful Action on Climate Change. In: The Routledge Handbook of Environment and Communication edited by Anders Hansen, Robert Cox. London: Routledge, 2015.

The Nation. 2013. The Fracking Industry's Dishonest Response to 'Gasland'. 18 November. Accessed 10/10/2018 at: https://www.thenation.com/article/fracking-industrys-dishonestresponse-gasland/.

National Assembly for Wales Research Service. Drilling down: the Welsh Government proposes policy to ban petroleum extraction. 2018. Accessed 12/10/2018 at: 
https://seneddresearch.blog/2018/09/06/drilling-down-the-welsh-government-proposespolicy-to-ban-petroleum-extraction/

Natural Gas Intel. Industry-Funded Truthland Film Opens in Ohio Sunday. 2012. Accessed 09/10/2018 at: https://www.naturalgasintel.com/articles/3246-industry-funded-truthland-filmopens-in-ohio-sunday.

The New York Times. 2012. Shale Gas Search Divides Romania April 22. The New York Times. Available at: https://www.nytimes.com/2012/04/23/business/global/shale-gas-searchdivides-romania.html

New York Times. Major Climate Report Describes a Strong Risk of Crisis as Early as 2040 New York Times, October 7, 2018a Accessed at:

https://www.nytimes.com/2018/10/07/climate/ipcc-climate-report-2040.html.

New York Times. 76 Environmental Rules on the Way Out Under Trump. New York Times, July 6, 2018b.. Accessed 09/10/2018 at:

https://www.nytimes.com/interactive/2017/10/05/climate/trump-environment-rulesreversed.html

The Observer. 2012. Huge scale of UK's 'dash for gas' revealed. The Observer, November 3, Accessed on 12/10/2018 at: https://www.theguardian.com/environment/2012/nov/03/ukdash-gas.

Piper, Ben and McQueen, David. How Successful Have Lobbyists Been at Influencing State and National Policy to Further the Completion of the Dakota Access Pipeline, Since the 2008 US Election? In Journal of Promotional Communications. Vol 6, No 1 (2018). 
Reuters. Germany to shut down pre-1980 nuclear plants. March 15 2011, Reuters. Accessed on 12/10/2018 at: https://www.reuters.com/article/germany-nuclear/update-3-germany-toshut-down-pre-1980-nuclear-plants-idUSLDE72E17620110315.

Reuters. U.S. fracking boom added 725,000 jobs -study. Reuters, November 6, 2016. Accessed 10/10/2018 at: https://www.reuters.com/article/usa-fracking-employment-studyidUSL8N13159X20151106.

Short, Damien and Anna Szoluchab. Fracking Lancashire: The planning process, social harm and collective trauma. Geoforum. 2017. Available at: https://www.sciencedirect.com/science/article/pii/S0016718517300519.

Spangler, Ingrid S., and Donnalyn Pompper. 2011. "Corporate Social Responsibility and the Oil Industry: Theory and Perspective Fuel a Longitudinal View." Public Relations Review 37: $217-25$.

Spence, David B. "Corporate Social Responsibility in the Shale Patch?” Lewis \& Clark Law Review 21 no. 2 (2017): 387-425.

Spiege., 2011. Helmut Kohl Weighs in on Reactor Debate. March 25. Spiegel Online. Available at: http://www.spiegel.de/international/germany/nuclear-moratorium-overly-hastyhelmut-kohl-weighs-in-on-reactor-debate-a-753125.html

The Telegraph. Jurassic Coast 'saved from industrialisation' as Navitus Bay wind farm rejected. The Telegraph, September 11, 2015. Accessed 15/10/2018 at: https://www.telegraph.co.uk/news/earth/energy/windpower/11859736/Jurassic-Coast-savedfrom-industrialisation-as-Navitus-Bay-wind-farm-rejected.html.

The Telegraph. Cuadrilla Lancashire Fracking Plans Cleared by High Court. The Telegraph. April 12, 2017. Accessed on 12/10/2018 at: 
https://www.telegraph.co.uk/business/2017/04/12/cuadrillas-lancashire-fracking-planscleared-high-court/.

The Times. Fracking protesters freed after judge criticises 'excessive' jail sentence. The Times. October 18, 2018.. Accessed on 22/10/2018 at:

https://www.thetimes.co.uk/article/fracking-protesters-freed-after-judge-criticises-excessivejail-sentence-v8t19nl3n.

U.S. EPA (U.S. Environmental Protection Agency). Hydraulic Fracturing for Oil and Gas: Impacts from the Hydraulic Fracturing Water Cycle on Drinking Water Resources in the United States. Executive Summary. Office of Research and Development, Washington, DC. EPA/600/R-16/236ES. (2016) Accessed 02/10/2018 at: https://cfpub.epa.gov/ncea/hfstudy/recordisplay.cfm?deid=332990. 